\section{Structural Studies on Group IV Metal Acetylacetonates}

Two types of six-coordinate complexes of acetylacetone (Hacac) with Group IV elements have been reported previously. They are $\left[M(\text { acac })_{2} \mathrm{Cl}_{2}\right](M=$ titanium, germanium, or tin) and $\left[M(\text { acac })_{3}\right]^{+}(M=$ titanium, germanium, or silicon $)^{1}$. The present communication describes the syntheses of other halides of the type $\left[M(\text { acac })_{2} X_{2}\right]$, infra-red studies on all the above complexes, and single crystel X-ray investigations on the three complexes [M(acac) $\left.{ }_{2} \mathrm{Cl}_{2}\right]$ ( $M=$ titanium, germanium, or tin).

Complexes of the type $\left[M(\operatorname{acac})_{2} X_{2}\right](X=$ fluorine, chlorine, or bromine) have been prepared by direct reactions of the metal tetrahalide with acetylacetone in an inert solvent. These complexes are diamagnetic, and behave an monomers and non-electrolytes in nitromethane and nitrobenzene. The absence of uncoordinated carbonyl absorption in the infra-red spectra of the complexes indicates that the acetylacetone groups are bidentate and therefore the metal atoms are six-coordinate. The essential point of interest with these complexes is whether they adopt the trans $(A)$ or cis $(B)$ configurations (Fig. 1).

The metal-halogen stretching frequencies $v(M X)$ for the complexes are given in Table 1 . In the spectra of the fluoro-complexes, only one $M F$ stretching frequency is observed near $600 \mathrm{~cm}^{-1}$, and this may indicate that the fluorine atoms are in the trans-octahedral positions, as are the methyl groups of the complex $\left(\mathrm{CH}_{3}\right)_{2} \mathrm{Sn}$ (acac) $)_{2}$ (refs. 2 and 3); however, some mixing of $M F$ with $M O$ stretching vibrations is to be expected. Two $M X$ stretching frequencies are observed in the infra-red spectra of the complexes $M(\mathrm{acac})_{2} \mathrm{Cl}_{2}$ and $M(\mathrm{acac})_{2} \mathrm{Br}_{2}$, suggesting the cis-octahedral arrangement of the ligands in these cases. This result is in agreement with the nuclear magnetic resonance results for $\mathrm{Ti}(\mathrm{acac})_{2} \mathrm{Cl}_{2}$ (ref. 5) and for $\operatorname{Sn}$ (acac) $)_{2} X_{2}\left(X=\right.$ chlorine, bromine, or iodine) ${ }^{6}$ in organic solvents. The $M X$ stretching frequencies are in the order $v(\operatorname{Sn} X)<v(\mathrm{Ge} X)<v(\mathrm{Ti} X)$ consistent with their expected mass dependence.

The complexes of the types $\left[M(\mathrm{acac})_{3}\right]+\mathrm{FeX}_{4}-(M=$ titanium or germanium; $X=$ chlorine or bromine) absorb at different frequencies, however, namely $\sim 377$ and $\sim 290 \mathrm{~cm}^{-1}$ for the chlorides and bromides respectively. These bands are clearly attributable to the $\nu_{3}\left(t_{2}\right)$ modes of the $\mathrm{FeX}_{4}-$ ions ${ }^{7}$, and hence confirm the presence of these ions in the complexes as originally inferred from electronic spectra and other sources of $\operatorname{data}^{8,9}$.

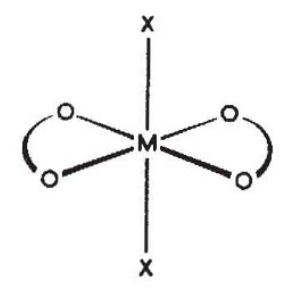

(A)

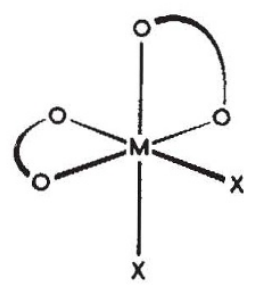

(B)

Fig. 1. Trans $(A)$ and cis $(B)$ forms of $M(\text { acac })_{2} X_{\mathrm{B}}$. (Hacac $=$ acetyl acetone, the ring being represented schematically.)
Table 1. Metal-Halogen Stretching Frequendiss in Complexes of THE TYPES $M(\mathrm{ACAC})_{2} X_{2} \Delta \mathrm{ND}\left[M(\mathrm{MCAC})_{3}\right]^{+} \mathrm{FE} X_{4}^{-}-$

\begin{tabular}{|c|c|c|c|}
\hline \multirow[b]{2}{*}{ Compound } & \multicolumn{3}{|c|}{$M X$ stretching frequencies $\left(\mathrm{cm}^{-1}\right)$} \\
\hline & & & $v_{3}\left(\mathrm{Fe}^{\prime} X_{4}\right)^{-}$ \\
\hline $\mathrm{Ti}(\mathrm{acac})_{2} \mathrm{~F}_{2}$ & & $629 \mathrm{vs}$ & - \\
\hline $\mathrm{Ti}(\mathrm{acac}){ }_{2} \mathrm{Cl}_{2}$ & $315 \mathrm{~m}$ & $373 \mathrm{vs}$ & - \\
\hline $\mathrm{Ti}(\text { acac })_{2} \mathrm{Br}_{3}$ & $246 \mathrm{wm}$ & $304 \mathrm{vs}, \mathrm{br}$ & \\
\hline$\left.\left[\mathrm{Ti}(\mathrm{acac})_{3}\right]^{+} \mathrm{FeCl}_{6^{-}}-\mathrm{Fec}_{3}\right]^{+} \mathrm{FeBr}_{4}$ & - & 二 & 379 vs \\
\hline $\mathrm{Ge}(\text { acac })_{2} \mathrm{Cl}_{2}$ & $296 \mathrm{~s}$ & $347 \mathrm{~s}$ & $201 \mathrm{vg}, 200 \mathrm{sL}$ \\
\hline $\mathrm{Ge}(\mathrm{acac})_{2} \mathrm{Br}_{2}$ & 241 wm & 283 vs, br & - \\
\hline$\left[\mathrm{Ge}(\mathrm{acac})_{3}\right]^{+} \mathrm{FeCl}_{4}-$ & $\cdots$ & - & $376 \mathrm{vs}, \mathrm{br}$ \\
\hline $\begin{array}{l}{\left[\mathrm{Ge}(\mathrm{acac})_{3}\right]^{+}} \\
\mathrm{Sn}\left(\mathrm{acac} \mathrm{F}_{2}\right.\end{array}$ & - & $581 \mathrm{vs}$ & $293 \mathrm{v8}, 283 \mathrm{~m}$ \\
\hline $\mathrm{Sn}(\mathrm{acac})_{2} \mathrm{Cl}_{2}$ & $264 \mathrm{~m}$ & 334 vB & $\ldots$ \\
\hline $\mathrm{Sn}(\mathrm{acac})_{2} \mathrm{Br}_{2}$ & $<200$ & $260 \mathrm{vs}$ & - \\
\hline
\end{tabular}

vs, Very strong; s, strong; m, mediun; w, weak; br, broad; sh, shoulder.

X-ray powder photographs show that the complexes $\left[M(\mathrm{acac})_{2} \mathrm{Cl}_{2}\right]$ ( $M=$ titanium, germanium, or tin) are not isomorphous with one another, although there is some similarity between the patterns for the germanium and tin crystals. Single crystal studies have given the following results:

$$
\begin{array}{lll}
\text { Titanium } & a=11.315 & \alpha=96.4^{\circ} \\
& b=8.074 & \beta=99.25^{\circ} \\
& c=9.040 & \gamma=87.0^{\circ} \\
\text { Germanium } & a=7.50 & a=84.9^{\circ} \\
& b=11.46 & \beta=87.4^{\circ} \\
\text { Tin } & c=8.164 & \gamma=88.16^{\circ} \\
& a=14.00 & \beta=107.5^{\circ} \\
& b=7.82 & \\
c=13.84 &
\end{array}
$$

It is of interest that the molecular volume of the titanium compound ( $\left.405 \AA^{3}\right)$ is much larger than that of the germanium and tin compounds $\left(349\right.$ and $361 \AA^{3}$ respectively). Owing to the low symmetries of the unit cells, it is not possible to assign molecular symmetries without full structural determinations. Full three-dimensional data have been collected, and are in the process of refinement.

Hatfield College of Science and Technology,

Hatfield, Herts.

$$
\text { M. } \operatorname{Cox}
$$

R. J. H. ClakK
H. J. MILLEDGE

William Ramsay and Ralph Forster Laboratories,

H. J. MILIEDGE

University College,

London, W.C.1.

Received November 4, 1966.

1 Cox, M., Lewis, J., and Nyholm, R. S., J. Chem. Soc., 6113 (1964).

2 MeGrady, M. M., and Tobias, R. S., J. Amer. Chem. Soc., 87, 1909\}(1965).

Kamasaki, Y., Tanaka, T., and Okawara, R., Bull. Chem. Soc. Japan., 87, 903 (1964).

- Nakamoto, K., Infrared Spectra of Inorganic and Coordination Complexes (Wiley, New York, 1963).

5 Bradley, D. C., and Holloway, C. E., Chem. Commun., 284 (1965).

- Smith, J. A. S., and Wilkins, E. J., Chem. Commun., 381 (1965).

'Clark, R. J. H., and Dunn, T. M., J. Chem. Soc., 1198 (1963).

Fackler, J. P., Woodruff, R. J., and Marini, J. C., Inorg. Chem., 3, 687 (1984).

' Ong, W. K., and Prince, R. H., J. Inorg. Nucl. Chem., 27, 1037 (1985).

\section{Effect of Uranium on Catalysts containing Metals of Group VIII of the Periodic System}

DuRING the course of investigations of catalysts for use in reactions between steam and hydrocarbons, it was found that by introducing uranium to the catalyst formulation a marked improvement in the reaction parameters was obtained.

The catalysts are prepared by impregnation of an inert support with the metal salts, the support being in the form of pure $\alpha$-aluminium oxide. A preliminary physicochemical examination of catalysts containing uranium indicates that uranium is probably acting as an olectronic promoter.

The first study carried out was on the effect of uranium on the total specific surface area of the catalysts, the surface area being measured by nitrogen adsorption. It was found that the addition of uranium to the nickel- 